88.

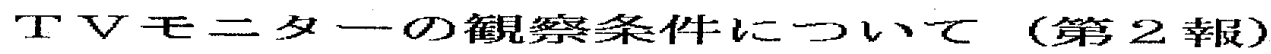

About Condition of Observation on Fluoroscope Monitors -The Second Edition-

\author{
関東遇信病院○若菘 焂SU

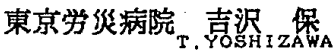 \\ 心研付属病院 镸谷川皆界

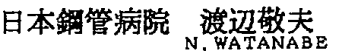

\section{今. 井寅雄}

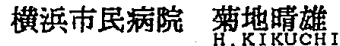

昭和大学病院 虫摆簙志

千架県立鶴無病院 佐藤㳄男

\section{聖路加国際病院 神嶛屚洋}

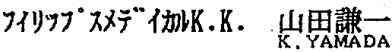

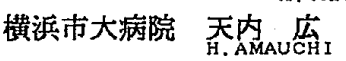

1. 目 的 第46回春季学会で、シネ撮影系における TVモニターの観察条件について 調査を行い、その調查結果より送像に対する受像のモニタ一輝度が一般に知られている理論值と同程度 の値を示したことでモニターの至適観察条件の設定が可能ではないかと報告した。今回もシネ撮影用総 合ファントムとパターンジェネレーターを用いてモニターの輝度を測定し、前回の測定方法の逆の立場 から至適観察条件の設定が今回の湘定方法で可能であるか検討を行ったので報告する。

2 - 万 法 測定方法は前回と同様に行い、モニターの至適観察状態への調整は日本医用 画像工学会のC S P委具会勧告の方法と奏験者の視覚により行った。

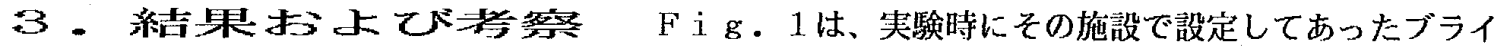
トネス・コントラストを動かさずそのままの状態で明室にて測定したモニター嗤度を表す。横軸にファ ントムステップを取り、それに対するモニター輝度の值を示す。施設により違った傾向を示し、一貫性 がない。湘定したモ二ターの状態は I が比較的新しく、K，Sは少化のあるモニターであった。

F i g.2 2 モ、モニーのコントラスト、ブライトネスの調整を行い、それぞれのモニターが最も良 い状態に設定されたものとしてFig. 1 と同様に輝度を測定し、各シネ撮影装置での装置間の差をノーマ ライズした値を示す。グラフの傾きは同様の值を示し、至適観察状態でのモニターの特性を示している ものと思われる。コントラスト歪みの部分は 10 カンデラ以下の值を示すが、この明るさはほぼモ二タ 一の撮像部分が回りより少し明るくなったぐらいの輝度である。F F g . 3 は、モ二ターにパター ンジェネレーターを接続し、調整前のモニターを暗室の状熊で輝度測定した結果を示す。パターンジェ ネレーターの出力信号は暗室湘定の状態ではモニター輝度に対しコントラスト歪必無くなり、最もい い状態のモニターでは直線性を示すはずだが、I を除いては直線性を示していない。

F i g.4は、Fig. 3の調整後の輝度湘定の值を示す。各モニターとも直線性を示し、パターンジェ ネレーターの出力すなわち送像の信号に対し、受像が正確に行われていることを示す。

1 - 結 論 いままで述べてきたことを総括すると、モニター輝度の調整はモニターの出 化および検查時の周辺照度の変化に伴い定期的に行うべきであるものと考える。CRTの調整方法は日 本医用画像工学会のC S P 委員会针告の方法があるがこの方法では明るさが少なくそれよりもブライト ネスを少し上げ、撮像されていない状態で $5 \sim 10$ カンデラ程度の輝度にしたほうがよい。コントラス 卜の調整は施設の周辺照度および好みの問題もあるので施設で適切に行ったほうがよい。実際の管理と しては装置管理をおこなう時に厚さの違う銅板を使い、毎回同じマニアル条件にてX線を出力し、その 時のモ二ター輝度を測定することで、良い状態でのモニター輝度の测定値と比較して管理すればよいも のと考える。また、パターンジェネレーターがあれば調整の確䜀が容易であるものと考える。

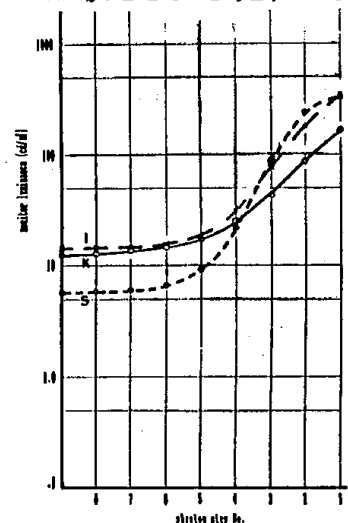

Fig. 1

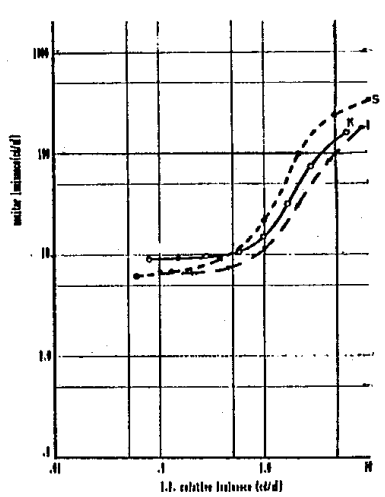

F i g. 2

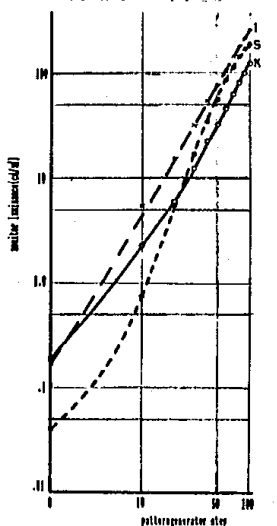

F i g. 3

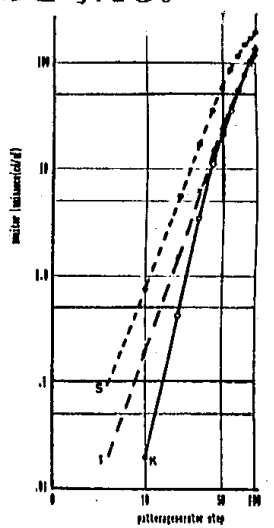

F i g. 4 